\title{
Self-Division in Selected Poems of Suad Al-Sabah.
}

\section{Submitted by}

\author{
Fatma Abd El -Azeez El-Gendy
}

\begin{abstract}
Al-Sabah represents the voice of oppressed women all over the world. She refuses all kinds of oppression especially those directed to women and calls for women liberty and equality to men. Al-Sabah is a fighter of women rights, yet she can never hide the Feminine traits of her character. She is wavering between her desire to fight against a male's Dominance, brutality and selfishness and her desire to adore him and seek his closeness. This Self-Division appears in Al-Sabah's chosen poems and highlights the theme of Feminism.
\end{abstract}

Self-Division Feminism Feminine traits Dominance

\section{Introduction}

This paper investigates the self-division of Al-Sabah's character. She is a feminist fights against a male, yet she is a female falls under his spell and needs his existence. It seeks to analyze some selected poems of Al-Sabah to explore the state of fluctuating between love and hatred in her poetry. This paper dives in Al-Sabah's reluctant psyche as she expresses love in some poems; meanwhile, she expresses hatred in others in a confusing way. This swing between adoring and abandoning uncover Al-Sabah's inner conflict and self-division.

This paper relies on a feminist overview, as it reflects Al-Sabah's feminist vision. She advocates feminism as a way which enables women to decide alone with no one to control her choices and destiny. It exposes Feminism as a way to get rid of a male's dominance and selfishness to deal with him as a lover and a friend. Through this paper, we realize that Al-Sabah is squeezed between love and hatred as she shifts between the two feelings throughout her poems. She lives under the pressure of her commitments towards love in one hand and her commitments towards the oppressed women of her tribe on the other hand. She is torn between what she is expected to be and what she really wants to be: between what she is expected to do and what she really wants to do. These psych divisions are the core of feminism as it aims at setting all women free out of the jail of social stereotypes. It evokes women to choose their own way away from those stereotypical drawn ways.

Throughout her chosen poems, we notice that Al-Sabah is hesitant between fighting against the male and expressing the great love and respect towards him. Adnann Aobidat and zuhair Aobidat argue in their article "Al-Badawia Ala'shekah" that "... she expresses her deeply devotion and exceptional love with her husband "Abdullah Al-Sabah" in one hand and her refusal to the domination of the male on 
the other hand" (185). In her poem "Al-Kamar Wa Al-Wahsh"1 or "The moon and the monster", Al-Sabah depicts that conflict saying:

Two desires are struggling deep inside.

The desire of being your beloved

And my fear of being your prisoner

Deep in me, the moon struggles with the monster

The black and the white

The Existentialism and the Sufism,

The desire of your connection,

And the desire of your assassination. (1-8).

Here Al-Sabah expresses the great conflict she feels inside. In spite of being a feminist and a woman rights warrior who fights against males' gender, she cannot prevent herself from falling in love. She wishes to be his beloved but she fears that she may lose her freedom falling under his domination's fist. Al-Sabah draws a wonderful visual image to express this struggle saying; "Deep in me, the moon struggles with the monster." In such a wonderful metaphor, she likens her feminine being to the moon with its innocence and brightness and likens a male to the monster with its superior power and strength.

Al-Sabah completes her idea describing more contradictory images which reflect the state of the conflict she feels inside. In the image of "The black and the white" she admits that a male and a female are two contradicting colors but they both are necessary to the existence of the other. "The Existentialism and the Sufism" is another contradicting image whereas she confesses that the existence of a male in a female's life is one of the basic elements for life to be continued and abandoning him is some sort of "Sufism" which means to discard all pleasures of life. Al-Sabah puzzles over her conflicting psyche: She desires to be connected to her beloved whom she is supposed to hate and terminate due to his oppression as a male, she says; "and the desire of your connection, / and the desire of your assassination." This image reflects Al-Sabah's dilemma; she cannot choose between her heart and her mind. Al-Sabah keeps using "and" to list the many ambivalent feelings she suffers inside in a fast subsequent way.

These consecutive contradicting images reflect the deep self-division and confusion which Al-Sabah engaged in. She loves, hates, fights and seeks

1 There is no authorized translation to this poem, so this poem is translated by the researcher 
a male's connection at the same time. She cannot control her feelings and she cannot give her mind the upper hand over her heart. In the seventh stanza, AlSabah highlights her role as a feminist who defends women rights saying:

Inside me,

Long women's marches

And slogans which are written with lipsticks.

And flags which are made of

Old socks' fibers,

And protests against the system of the mono part,

And the only male

With many females' nationalities in one bed. (51-52, 55 $60)$.

Throughout this stanza, Al-Sabah exposes her role in the feminist movements. She is a participant and organizer of the women marches which call for women's liberty and equality between genders. Al-Sabah rejects all kinds of oppression especially those directed against women and offers a hand of help for all depressed women all over the world. She describes herself saying: "I consider myself a conscript in the service of right, equality, and freedom. I cannot be marginalized about what happens before me as a woman and as an Arab citizen" (Fawzy 51).

In this stanza, Al-Sabah goes on depicting her inner psych dispersion. AlSabah keeps reminding herself with her feminist principles, with her long journey as a feminist and those long marches she organized and still to free women out of the male's fist to prevent herself from yearning for her beloved. Along with the image of: "And slogans which are written with lipsticks,/ And flags which are made of /old socks' fibers,"(55-57); Al-Sabah utilizes a unique technique as she exploits the feminine items which supposed to be used by all women to make themselves beautiful and to amuse men as weapons to fight men. The unusual collocations of "logos" written with "lipsticks" and "flags" made of "sock's fibers" provokes the reader's mind. They highlight the perspective of feminism as Al-Sabah uses the same feminine items which assigned to serve men against them refusing women traditional role as mothers and wives and calling for women rights for work. She exploits the terms of "old socks" and "lipsticks" as metonyms for women and the social stereotypical images about women's work. 
Al-Sabah fights against the oppression of both males and society as they deprive women of their rights. They restrict women's work in raising children and cooking meals. Al-Sabah says; "only men are allowed to put the plans of development. Meanwhile, women are prevented from participating in social, economic and political development. A woman cannot even choose the names of her own children. Her choices have been restricted to the menu of food and the colors of her dresses and shoes. (Fawzy 118). Therefore, Al-Sabah's diction and usage of those feminine terms was a perfect choice. They reflect the gender role stereotypical images about women as wives and mothers. Throughout these feminine items, AlSabah aims at proving that women cannot be caged home fearing of their insurrection and revolt as they used the items of their cage as weapons against the jailer. They are smart and nothing can hinder them achieving their independence and liberty.

Al-Sabah seeks to gain women rights and to set all oppressed women free out of the jail of the male's dominance. She rejects the state of Arab women as silent dolls and calls for women's equal rights as human beings. Adnann Aobidat and zuhair Aobidat argue in their article "Suad Al-Sabah: Al-Badawia Ala'shekah" that: "she rejects the state of the Arab women as obedient women who have no opinion or choice but to obey the male's orders, but at the same time she subjugates to the male's authority represented in her husband (185). It seems that no matter if AlSabah struggled with a male as she cannot hate or abandon him and still seeks his closeness and connection. In her eighth stanza, Al-Sabah says:

Just after the ending of the demonstration

Whereas the combs return to their sheath

And the rings return to their drawers

And the perfumes return back to their flasks

I let go of my placard

And forget about my protests

And I search for you in any close café

To have coffee with you. (61-68).

Al-Sabah depicts one of those demonstrations in which women use all the kinds of weapons they have: "combs", "rings" and "perfumes" against men. Again and again, Al-Sabah uses these feminine tools to highlight the perspective of feminism and the gender role stereotypical images which women fight against. Men and society restrict women role in amusing men: they are stereotyped as pretty wives dwelling in homes, twinkling in jewels, combing their hairs, putting perfumes and make up to attract their husbands. Al-Sabah reverses the feminine items of amusing men to swords pointed to them. "Combs", "rings" and "perfumes" are also 
metonyms for women's tenderness and another reflection to women's ability to love and to fight if oppressed. They as well are unusual collocation as women replace swords with combs and shields with rings to prove their intelligence and good management. As the war ends; the combs return to their sheath, the rings return to their drawer and the perfume return to their flasks. These visual images are wonderful metaphors which liken those items to human beings who have the ability to move and return back to normal state. Al-Sabah as well seems to return to her beloved who seems to be her only refugee after all.

Thus, Al-Sabah reaches the top of her inner conflict. After the semi-war demonstration, she is looking for the same male whom she fought against to have coffee with him and feel pleasure in his closeness. It is not schizophrenia; it is rather a normal attraction to her other half. No matter what are the differences and disputes; both of the two genders complete each other and no one of them can terminate the other or abandon him as that means the termination of the humankind. She cannot simply deny the male's existence and her need for his presence; she rather wants him to admit the importance of the female's role.

Al-Sabah is still squeezed between what she really wants and what she is expected to do. She wants to be connected to her beloved and at the same time she wants to fight his oppression. In the third stanza of "Twasulat"2 or "petitions" poem, she depicts the conflict she faces between her love and her feminist commitments saying:

\section{I beg you}

Don't crush me

Between my romantic commitments to you

And those historical ones towards my tribe. (15-18).

Here, Al-Sabah confesses her feeling of love and accepts its domains. The title holds lots of humiliation and reflects Al-Sabah's respect to her beloved and husband. Contrary to her last poem with lots of demonstrations against the male's dominance, she welcomes the dominance of the male and humbles herself to his authority and orders. Moreover, she begs her beloved and asks him in a humble way not to squeeze her between her commitments towards love and her commitments towards the depressed women of her tribe as they always depend on her words to gain their rights.

2 There is no authorized translation to this poem, so this poem is translated by the researcher 
In her volume "Khothnee Ela Hodood Al-Shams" or "Take me to the borders of the sun" specifically in "Sa'abka Aohebok"3 or "I will always love you" poem, Al-Sabah the hesitant self-divisor poet shifts again to the completely subjugated woman, she says:

O... little dictator

I do not blame you whatever you have done

And even if you suppressed my feelings

And even if you broke my imagination. (49-52).

Al-Sabah begins the fourth stanza flirting with the male saying; " O... little dictator". Al-Sabah combines "O... little" to "dictator" in an unusual collocation and she deals with the male as if he is her pampered baby. The word "dictator" is a masculine trait which reflects the male's aggressiveness and domination. Al-Sabah turns a blind eye to the male's oppression and selfishness and all his faults are justified. She does not oppose his oppression as a little rush dictator or blame him for his dominance, insanity and foolishness. She throws away her revolutionary principles and accepts his tyranny and whatever he does to her, she welcomes it.

In contrary to her previous poem, Al-Sabah -here- really enjoys the dominance of the male and asks for more "... She vowed herself to call for women's rights, pride and self-confidence ... On the contrary, she wrote about the woman's love to the male and the awesome feeling of his sovereignty over her." (Soliman n.p.) Furthermore, she is giving him all the excuses and the green light to make more faults as they all will be justified.

$$
\text { O... my Sir : }
$$

Pardon my insanity

As my fantasies are rudimentary

And my passion-as me- rudimentary

I will always love you

Even if I got bored

And even if I got yield

And even if I got protested

And even if I wanted to get rid of my Arabic Kohl

And my chestnut hair

3 There is no authorized translation to this poem, so this poem is translated by the researcher 
I will always love you. (59-69).

Here, Al-Sabah uses the term "O... Sir" or "Yasaiedee" to reflect her great love and respect to the male and her humiliation towards his orders. She appears as a subjugated woman to the male's authority and will on the contrary to the history of her demonstrations against him. When Fawzy said: "You are speaking about the male with too much respect, she spoke in poetry saying: "The most precious achievement of my life is that I do love you" (Fawzy 19).

In this poem, Al-Sabah changes her attitude towards the male. She is throwing away her demonstrations to live in some harmony with her husband. Moreover, she begs the male's pardon for her insanity and apologizes for being demonstrating against him. She is giving herself some excuses as well so that the man may forgive her protests against him and know that she loves him for sure. She is a woman with an innate character with rudimentary, fantasies and passion. She announces that she devoutly loves him; even if she protested against him or got bored or screamed or yield, she will always love him. Al-Sabah highlights the element of her revolutionary character as she refuses and demonstrates against any boundaries or jails. Moreover, she wants to get rid of her Arabic Kohl and chestnut hair. Therefore, she proves her love and devotion to the male claiming that her demonstrations are a normal deed of her character.

We touch the instability of Al-Sabah's emotions clearly as sometimes she puts fire on the male and in other moments she closes down the shoot and write about falling in his love with great passion. In her poem "Thwrat Al-Dagag AlMogalad" 4 or "The demonstration of frozen chicken", Al-Sabah's self-division appears clear whereas she throws away her passion with the male and turns against him promising to avenge the women's tribe on that oppressive male by killing him. She says:

I will announce on behalf of Suad,

Hend,

Lubna

And on behalf of Battool

That I will announce on behalf of thousands of frozen chicken

In the name of thousands of canned chicken.

That I suffocated you under my braids

4 There is no authorized translation to this poem, so this poem is translated by the researcher 
And that I drank your blood as alcohol

And I will

Not break my word. (1-9).

Al-Sabah opens her poem with an announcement. It is a letter of revenge commitment; whereas she promises on behalf of herself and all oppressed women that she will take their revenge. She promises to announce one day that she suffocated the male using her braids. Moreover, she aims to drink his blood as Alcohol as an act of revenge. This bloody poem is completely different from those in love poems. Through her bloody thoughts, Al-Sabah seems too moody in her reactions; she promises to kill and deform his body.

She seems to know her moody character that is why she promises that this time she will keep her word and will not go back out of her word "And I will not break my word". Al-Sabah uses some feminine names as "Hend, Lubna and El Battool as a synecdoche, whereas she uses the part to indicate the whole female gender. Al-Sabah uses a metaphor to liken women to chicken (frozen and canned) in an awful image: this awful resemblance reflects the ill-treatment of women. It is a metonym for the women's offense and the social perception of women as mean commodities can be bought and sold. Al-Sabah goes further in her threats:

I will throw to the sea

My feminine wears

And burn all the boats before they reach

I will announce $-\mathrm{O} \ldots$ rooster-

That I avenged

All the tribe's women on you

And that I slapped you

Twice,

Three times

And four times

And that I buried you under the ruins

And I will not break my word. (10-21).

In "Feminine wears" image, Al-Sabah exposes the theme of self-division as she expresses the reciprocal natural need to the male's gender, yet she insists on 
abandoning her beloved. In a rejecting action, she vows to burn her feminine wears to fight back her natural attraction towards Male. Moreover, she wants to burn them to make sure that she will not break her words and wear them once more. Again, she highlights the perspective of feminism whereas she refers to those seductive feminine clothes which women wear to please their husbands and refuses to be a tool of amusement for such oppressor. She employs the gender role stereotype perspective to show the social stereotypical image of Females as entertainment tools created to amuse Males. It is a synecdoche which mentions the part "Feminine wears" to indicate the whole Females' gender traits.

Once more, Al-Sabah reflects the feminist perspective by using terms which advocate/ indicate masculine traits such as "boats" and "rooster". Al-Sabah vows to burn the males' boats so that she will not be able to withdraw her commitment and see her beloved again. She promises not only to end her relationship with her beloved but to terminate him completely by burning the males' boats before they land. The poet utilizes metaphor as she likens a male to (a rooster) and this metaphor reflects the selfishness of the male who wants to be the only dominator and all chicken that symbolize women around him work hard to amuse him and make him satisfied.

In another bloody visual image, Al-Sabah aims at slapping the male represented in the rooster many times as a revenge action. Moreover, she will bury his dead body to make sure that he is done and will not come back again. Al-Sabah seems so satisfied and content with her revenge. She assures once again that she will not break her words this time. The hatred feelings which Al-Sabah shifts to after her love poems, assure the element of Al-Sabah's inner conflict and highlights the theme of self-division. Al-Sabah keeps her reader in his suspense wondering what for these bloody acts of revenges till the third stanza whereas she says:

I will avenge

Those confused and patient ones

And the underage girls whom you bought their virginity

Like seeds and fields

I will scream

On the behalf of the virgins whom

You married

And divorced

The same as you buy and sell horses

O... lover, 
Who does not distinguish in love game

Between women's flesh

And calves' meat

I will scream

Till the downfall of the skies

Over my head and yours; my sir

And I will not break my word. (22-38).

Al-Sabah wants to avenge those underage virgin girls on that reckless lover who deceived them under the name of love. This careless guy marries the underage virgins as easy as he buys some seeds. He owes them under his service the same he owes a field or a piece of land. Neglecting their feelings; he marries and divorces them the same way he buys some horses and sells them. Al-Sabah accuses that rush lover of being an incurious one who does not care to know the difference between the women's flesh and that of the calves. It is the same metaphor of the frozen and canned chicken whereas males consider women a commodity bought and sold.

She promises to get rid of him avenging those deceived girls even if she screams until the downfall of the skies over his and her head. Al-Sabah is ready to sacrifice herself if that means getting rid of the selfish male. This selfish man represents the selfishness of the males who amuse themselves regardless of the other partners' feelings. Like all his male gender, this guy adores the play of domination, owing and replacing women as pieces of lands or goods. She confesses her moody character and takes a promise and some precautionary procedures to make sure she will not break her words this time and she will terminate the male with no way back.

In another aspect of Al-Sabah's self-division; Al-Sabah uses the term "O, Sir" or "Ya, Saiedee" ironically to despise the males' dominance and selfishness instead of expressing love and respect as in the rest of her poems. To the last line, Al-Sabah seems determined to avenge those girls of her kind no matter what will be the subsequences. Al-Sabah keeps shifting and fluctuating between love and hatred in a confusing way which reflects her inner conflict, she says in "Al-Magnonah" or "Mad Woman":

I am quite mad and you are wholly sane

From the mind's paradise, I've sought to flee

You are all wise, yours are the summer months

${ }^{5}$ This poem is translated by Abdul-Wahid Lu'Lu'Ah 
So leave the winter's changing face for me. (1-4).

In this poem, we recognize a totally different Al-Sabah. She is not the same one who fights against males and their domination trying to prove the self or the avenger who seeks to terminate the males completely. She opens her poem glorifying her beloved's holiness and maturity admitting herself of being mad and insane. She glorifies his wisdom describing him to the warmest season of the year (the summer season), as he sets her soul in fire of love. She likens herself to the winter; the coldest season whereas her inner psyche is full of storms and hurricanes and needs the male to overwhelm her.

I'm sick with love and I'm past any cure

Oppressed in body, that is woman's plight

My nerves are taut and should you only whisper

Into the empty air I would take flight. (5-8).

Al-Sabah abandons her pride and admits falling in love. She complains the state of conflict which eats her to the bone and has no hope to recover. In spite of being oppressed the same as all women of her kind, she is head over heel in love. She is "sick with love" and she has no cure. She is tired of abandoning and fighting against the male for whose sake she dies. This confusion she suffers inside makes her nervous and so destroyed. She goes further in expressing love saying:

I'm like small fish lost in the great ocean

When will you lift the siege? You've hidden away

The key to unlock my house in your own pocket

And enter my life's details day by day. (9-12).

She expresses the meaning of love which she believes to be a feeling of containment. She feels like a small fish in the big ocean of her beloved. This sweet visual image depicts the real meaning of containment and real love. Unlike her previous poem, Al-Sabah admits the domination of the male, asking him when he will open the siege and begging him in a humble way to lift the siege and to give her the keys of her house which he has hidden.

Comparing this poem to Al-Sabah's "the demonstration of frozen chicken" or "Thawrat Al-Dagag Al-Mogalad", the reader notices the self-division of AlSabah. Unlike her previous attitudes, she glorifies the male accepting his dominance instead of refusing her cage and calling for her liberty. He interferes in her daily details and dictates to her what to do. Al-Sabah seems so quiet and content with such dominance as she shows no objection. This confusion in attitudes supports the idea of Al-Sabah's self-division and the conflict which she is sick of. She adds; 
O love, my passion whirls me dizzily.

Gather my scattered soul whose fragments fly.

For you are standing at the frozen pole

And I beneath an equatorial sky. (13-16).

Al-Sabah seems so tired and broken in this poem; she is not the old strong fighter. She is sick of that love which controls her life and feels fainting and brokenhearted. She is begging her beloved to gather her fragmented soul again. Al-Sabah abandons those threats of the previous poem replacing them with the expression "O... my love" and instead of fighting against the male who cages her liberty, she complains about her flaming emotions in comparing to his cool ones. Al-Sabah completes her poem saying:

O love, I stand against the Ten Commandments.

To love I owe allegiance. Lemon trees.

Within your breast my only native land. (17, 19-20).

At the end of the poem, the revolutionary Al-Sabah accepts her cage and admits the male's dominance. In a totally self-division action, she breaks those commitments to the women of her tribe (see Tawasulat poem, stanza 3 line 4) and join the male's row. Moreover, she regards him as a king and offers him her loyalty and obedience. She ends her poem describing her beloved's breast to be her only homeland and offers him her devotion, loyalty and obedience. Comparing this poem to the "The frozen chicken" we notice that the two attitudes are contradicting. The moody Al-Sabah shifts between love and hatred so rapidly. This state of contradictions reflects the self-division of Al-Sabah and the inner conflict she suffers in deep.

Conclusion

One can conclude, therefore, that Al-Sabah seems to be torn between two contradicting feelings and two contradicting kinds of people. She is divided between her commitments towards her beloved on one hand and towards her tribe's oppressed women on the other hand. She is distracted between her love towards the male and her hatred towards his arrogance and dominance. She is always confused between her emotions and her reason and this confusion raises a huge conflict in her psych appears clear in her poems and helps in making her the self-divisor one she is.

Al-Sabah's attitudes vary from a poem to another each poem and sometimes we touch this confusion and self- division within the same poem. In some situations, she hates the male and protests against him fiercely, while she adores him and feels 
eager to meet him in other situations. In some situations, she despises a male rejecting his selfishness and oppression promising to terminate him and avenge her gender, while she regards him as a king and offers him her loyalty and obedience in other situations. Sometimes, she looks so confused standing in an ambivalent state of loving and hating. Other times, she admits his dominance begging him not to squeeze her between his love and her commitments towards the tribe's women. These confusions, oscillations and rapid shifts in emotions and actions reflect the self- division of Al-Sabah and the conflict she suffers inside.

Works Cited

Al-Sabah,Suad. "Al-Kamar wa Al-Wahsh". Aroos. 16 April 2008.

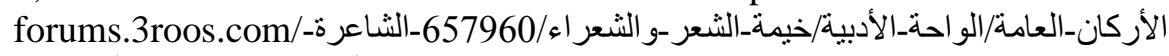
2.html. Accessed 8 June 2019.

---. "Mad Woman". Poem hunter. n.d. www.poemhunter.com/poem/mad-woman/. Accessed 10 June 2019.

---"Sa'abka Aohebok" Khothnee ela hodood Al-Shams. blogspot. wed. 25 April 2012. Suad Muhammed Al-Sabah. souadalsabah.blogspot.com.eg/2012/04/blog-post_25.html. Accessed 12 June 2018.

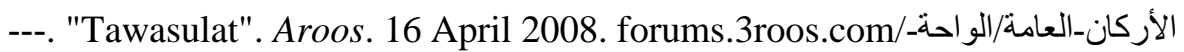

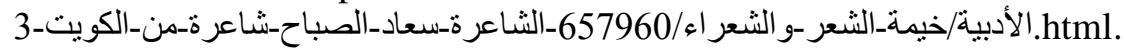
Accessed 10 June 2019.

---. "Thawrat Al dagag Al-Mogalad". Aroos. 16 April 2008.

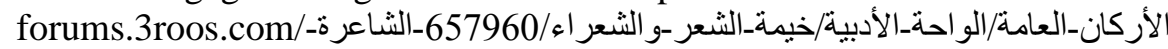
.سعاد_الصباح-شاعرة-من-الكويت-3tml. Accessed 20 June 2019.

Aobidat, Adnann. Aobidat. Zuhair. "Suad Al-Sabah: Al-Badawia Ala'shekah". Damascus Magazine. 2012. PDF.

Fawzy, Moufid. "Mafateeh kalb Sha'erah". Interview with Suad Al-Sabah. Egypt, the Egyptian general book organization. 2000.

Soliman, Gomana. "Surat Al-Mara'ah Fi She'ar Al-Sabah". Al-Thawrah Magazine. 9 Dec. 2005.

thawra.alwehda.gov.sy/_print_veiw.asp?FileName=9450759542005120812 3227. Accessed 5 Feb. 2017. 


$$
\text { الترجمة }
$$

انشطار الذات فى شعر سعاد الصباح

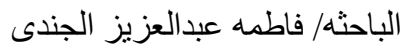

الملخص

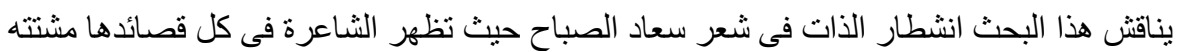

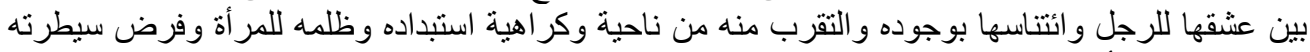

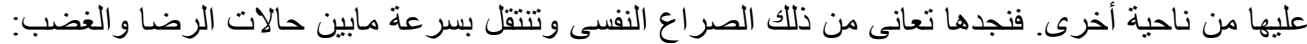

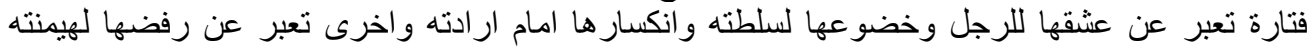

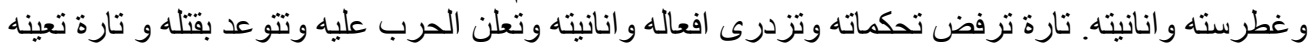

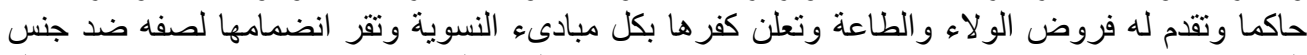

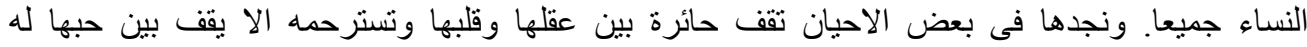

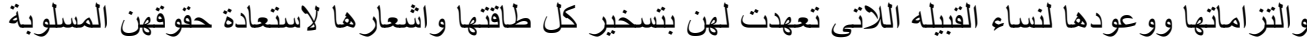

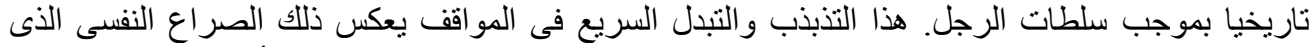

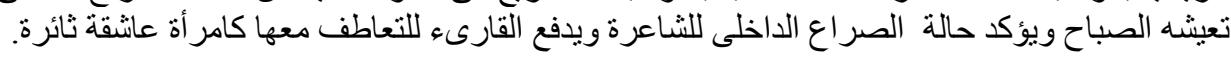

